\title{
遡上スワールにより形成された循環流領域を持つ マイクロガスタービン用燃焼器の燃焼特性*
}

\author{
新井雅 隆*1, 天野俊 輔*2, 藤 原秀智*3 Recirculation Zone Induced by an Upward Swirl
Masataka ARAI*4, Shunsuke AMANO and Hidetomo FUJIWARA
${ }^{* 4}$ Dept. of Mechanical System Engineering, Gunma University, 1-5-1 Tenjin-cho, Kiryu-shi, Gunma, 376-8515 Japan \\ Combustion Characteristics in a Micro-Gas Turbine Combustor with a
}

\begin{abstract}
The combustion characteristics of a prototype micro-gasturbine combustor fueled by kerosene were investigated. In order to enhance the recirculation in a primary combustion zone, a swirler was set between the primary and secondary combustion zones. Primary combustion air was introduced through the swirler and forced to flow upward to the combustor bottom, from where the fuel spray was supplied through a nozzle. The fundamental combustion characteristics such as lean combustion limit, flame luminosity etc. showed that this prototype combustor had a high potential for lean combustion and wide flame holding. Since a strong forced recirculation flow was induced by the upward swirl, lean and non-luminous flame was maintained in the primary combustion zone. Further, burned gas recirculation and highly turbulent shear flow in the primary combustion zone, both of which were caused by the upward swirl, resulted the low $\mathrm{NO}_{x}$ emission characteristics.
\end{abstract}

Key Words: Gas Turbine, Swirl, Combustion, Combustor, Spray Combustor, Low $\mathrm{NO}_{x}$ Combustion, Combustion Stability, Upward Swirl

\section{1. 粕}

近年, 大気污染および地球温暖化の防止, またエ ネルギーの多角的利用の観点から, マイクロガスター ビン発電が分散型電源の一つとして注目 ${ }^{(1-5)}$ を集めて いる. マイクロガスタービン発電用の燃料としては大 気污染防止の観点からは天然ガスの使用が望ましい. しかし，分散型電源としての利便性，非常時および災 害時の燃料確保の容易性, 燃料経済性などの観点から は液体燃料を使用する分散型マイクロガスタービン発 電の需要が今後高まると考えられる.

ガスタービン用の燃焼器ではタービンへ供給する 燃焼ガス温度に上限があることと低NOx 燃焼を行わ せるため, 希薄燃焼を実現することが技術的な課題 6 7)である. また, 熱効率の向上も大きな課題である. このため, 熱交換器を用いた燃焼用空気予熱との組み 合わせで一次燃焼領域の予混合化を目指した種々の燃 焼器の開発がすでに行われ，気体燃料の場合では予混 合方式(8-10)が提案されている. 液体燃料の場合でも予 蒸発方式 ${ }^{(11-14)}$ が，一次燃焼領域の希薄予混合化のため に検討されているが，技術的課題が多く，液体燃料用

\footnotetext{
* 原稿受付 2004 年 6 月 8 日.

*1 正員, 群馬大学工学部 (- 376-8515 桐生市天神町 1-5-1)

*2 正員, (株) 荏原総合研究所 (- 251-8502 藤沢市本藤沢 4-2 1).

*3 群馬大学大学院工学研究科.

E-mail : arai@me.gunma-u.ac.jp
}

の燃焼器では新しいコンセプトの燃焼器の開発が必要 になっている.

一方筆者らは, 噴霧燃焼器の内部で高温の燃焼力 スを一次燃嬅領域に循瑟させると, 高温低酸素雾囲気 により着火を抑えて㜣料の蒸発のみを促進することが でき, 高温低酸素燃焼との相乗作用により低 $N O x$ 燃 焼が可能であることを見出した! ${ }^{(15-17)}$ さらに，この作 用を強めるためには一次燃焼領域の末端から燃狫用空 気を上流に向かって導入し，この流れにより燃焼ガス の強制的な上流への移送を行う方式が効果的であると 考えた. ${ }^{(18)}$

本研究では, 上記の考え方に基づいたマイクロガ スタービン用の噴霧燃焼器を試作した. ここでは試作 した燃焼器における燃焼範囲, 火炎形状, 出口温度分 布等の基本特性の結果, および, 最適設計のための形 状パラメー夕選定等の考察を行った結果を報告する.

\section{2.おもな紀号}

$C_{p a}:$ 空気の定圧比熱

$\mathrm{J} / \mathrm{kgK}$

$C_{p}:$ 燃料蒸気の定圧比熱

$\mathrm{J} / \mathrm{kgK}$

$E I\left(N O_{x}\right)$ : 単位燃料あたりの $N O x$ の排出量 $\mathrm{g} / \mathrm{kg}$

$E I(C O)$ : 単位燃料あたりの $C O$ の排出量 $\mathrm{g} / \mathrm{kg}$

$H:$ 燃料の低位発熱量

$\mathrm{J} / \mathrm{kg}$

$L_{h}:$ 燃料の蒸発熱

$\mathrm{J} / \mathrm{kg}$

$M_{a}:$ 供給空気流量 
$M_{f}:$ 燃料供給流量

$r:$ 半径方向の座標

$\mathrm{kg} / \mathrm{s}$

$\mathrm{mm}$

$T H C$ : 末燃炭化水素 $\left(\mathrm{C}_{1} \sim \mathrm{C}_{7}\right.$ : メタン換算 $) \mathrm{ppm}$

$T_{a}:$ 燃焼器入口空気温度

$T_{g}:$ 燃焼カス温度

$Z_{c}:$ 燃焼器全体長さ

$Z_{p}$ : 一次領域燃焼简長さ

$Z_{s 1}, Z_{s 2}, Z_{s 3}$ : 二次空気供給位置

$Z_{t}:$ 一次領域燃焼筒十スロート長さ

$\eta_{c}:$ 燃焼効率

$\lambda:$ 空気過剩率

$\lambda_{p}:$ 一次領域空気過剩率

\section{3. 烧焼器内の流勒コンセプト}

試作した燃焼器内部の空気流れの概略を図 1 に示す. 本燃焼器の特徵 ${ }^{(18)}$ は一次燃焼領域の末端に設置した スワーラから出口方向とは逆向きに, すなわち燃焼筒 底部の燃料ノズルの方向に旋回流を導入している点で ある．導入された旋回流は上流に遡上し（Upward Swirl），底部のカイイドベーンによりノズル近傍に向か い, その後絞り部（Throat）を通過して二次燃焼領域 に流出する. ホローコーン状の燃料噴霧はスワーラに 向かって噴射され，火炎を形成する. 燃焼カススの一部 は流入する旋回流とともに上流に遡上するので, 噴霧

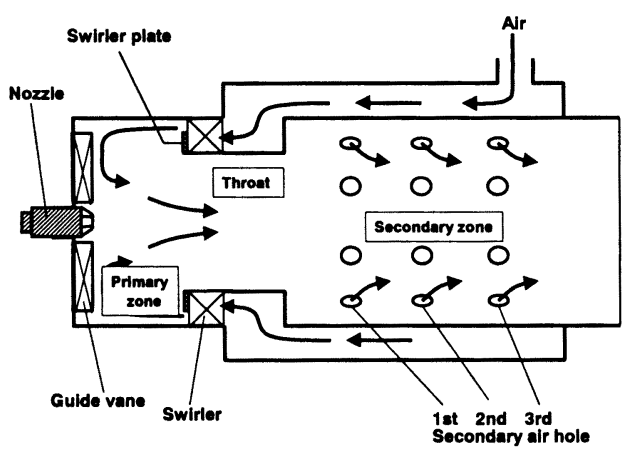

Fig. 1 Concept of upward swirl combustor

Table. 1 Split ratio of combustion air

\begin{tabular}{|c|c|c|c|c|}
\hline \multicolumn{5}{|c|}{ Split ratio of combustion air } \\
\hline Row & $\begin{array}{c}\text { Primary air } \\
(\%)\end{array}$ & $\begin{array}{c}\text { Secondary air } \\
(\%)\end{array}$ & $\begin{array}{c}\text { Primary air } \\
(\%)\end{array}$ & $\begin{array}{c}\text { Secondary air } \\
(\%)\end{array}$ \\
\hline Swirler & 100 & 0 & 100 & 0 \\
\hline $\begin{array}{c}\text { Swirler and } \\
\text { 1st }\end{array}$ & 55 & 45 & 62 & 38 \\
\hline $\begin{array}{c}\text { Swirler, 1st } \\
\text { and 2nd }\end{array}$ & 49 & 51 & 56 & 44 \\
\hline $\begin{array}{c}\text { Swirler, 1st, } \\
\text { 2nd and 3rd }\end{array}$ & 42 & 58 & 51 & 49 \\
\hline
\end{tabular}

の根元には高温低酸素雾囲気の燃焼ガスが供給される ことになる．この高温低酸素䨌囲気 ${ }^{(19-24)}$ により噴霧 の蒸発を促進し, かつ希薄低 $\mathrm{NO}_{\mathrm{x}}$ 燃焼を行わせるこ とが本研究の目的である.

試作した燃焼器では旋回流の導入方向を整えるため, スワーラの内周側をプレートで覆った. これはスワー ラの内周側をプレートで覆うことにより旋回流を強制 的に燃焼器の壁面側に治わせる狙いがある. このプレ 一トの有無, 二次空気孔の有無により流入する燃焼用 空気の配分が異なるため, それぞれの流入孔に単独で 燃焼用空気が流入する場合の圧力損失を基準に空気配 分比を求めた. 本研究で使用する流入空気孔の主な組 合せと空気配分比を表 1 に示す.

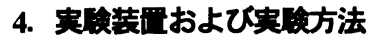

実験装置の概略を図 2 に示す. 燃料と空気の供給系, 温度測定系およびガス濃度サンプリング系から構成さ れている. 燃焼器断面を図 3 に示す. 燃焼器は, スワ 一ラ, 燃焼筒, 燃料ノズル, 点火プラグ, ガイドベー ンで構成されている. 燃焼筒は一次と二次領域の直径 $136 \mathrm{~mm}$, 一次と二次領域をつなぐスロート部分の直径 $96 \mathrm{~mm}$ ，長さ $560 \mathrm{~mm}$ の円筒である. 一次領域の底には 燃焼ガスを燃料ノズル近傍に導くためのガイドベーン

（A-A 断面）を設置した. またスワーラからの流れを 絞りライナーに浻った流れにして遡上する旋回流が一 次領域の底まで到達できるように, スワーラプレート （B-B 断面）を取り付けた. 二次空気は直径 $13 \mathrm{~mm}$ の 空気孔 8 箇（C-C断面）より供給した. 燃料噴射ノズ ルには噴霧角 90 度のスワールノズル（Delavan 社製, 3.00gallon $\left./ \mathrm{h} 90^{\circ} \mathrm{A}\right)$ を使用し燃焼器の軸上に配置した. 燃料には灯油を使用し, 高圧ポンプで加圧して供給し た.ノズルの定格流量である 3.00gallon/h た灯油（密度 $790 \mathrm{~kg} / \mathrm{m}^{3}$ ) では $25 \mathrm{~g} / \mathrm{s}$ に相当するが，こ れ以下の流量では微粒化特性が悪化するため, 本研究 では $2.5 \mathrm{~g} / \mathrm{s}$ 以上の流量で実験を行った. スワーラの内 径は $97 \mathrm{~mm}$ で, 羽角度 $45^{\circ}$, 羽枚数 16 枚のものを使 用した。

ブロアからの燃焼用空気 $M_{a}$ は, 表 1 に示した配分 比でスワーラおよび二次空気孔から燃焼器に供給され る. 二列の二次空気孔とプレート付きのスワーラの組 合わせを基本に，以下に述べる燃焼実験を行った. 燃 焼器出口の燃焼ガス温度 $T_{g}$ は Pt-PtRh 熱電対を用いて 測定した. 燃焼器出口の排ガスは水冷プローブでテト ラバックに採取し，自動車用排気カス測定装置（堀場 製 MEXA-4000FT）で分析し，メタン換算 THC $\left(\mathrm{C}_{1} \sim \mathrm{C}_{7}\right) ， \mathrm{CO}, \mathrm{NOx}$, の濃度を測定した. 


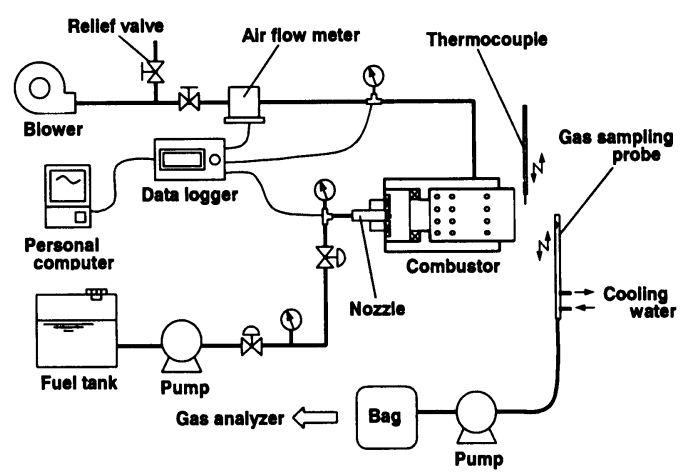

Fig.2 Experimental apparatus

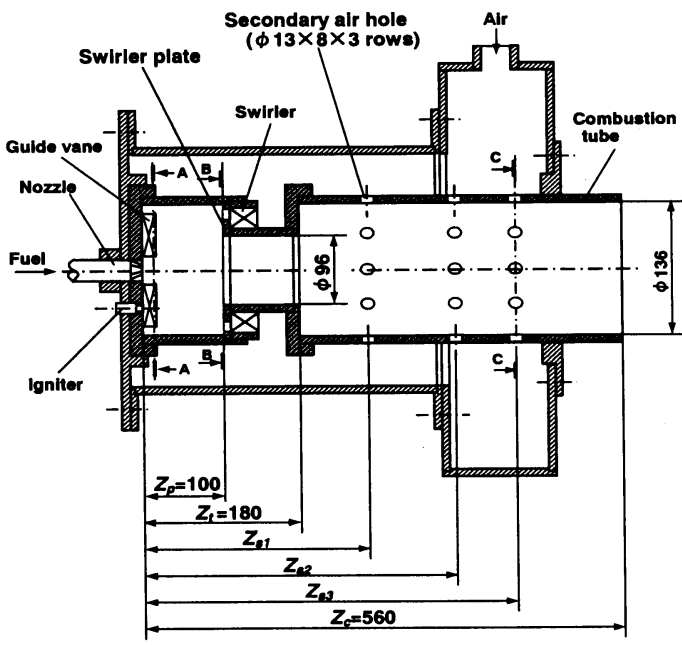

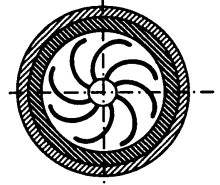

A-A

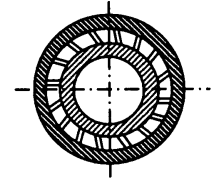

B-B

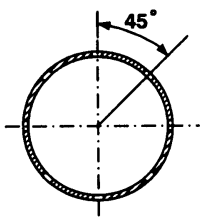

c. c
Fig.3 Schematics of test combustor

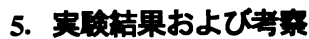

$5 \cdot 1$ 烚焼特性 目視による燃焼状態の観察結果 を表 2 に示す．また，基本的な燃焼特性を図 4 に示す. 火炎の状態を以下に示す 3 つに分類した.

（1）吹き消えが起こる領域（燃焼特性図中(1)）

（2）青色の不輝炎，または一部輝炎が不輝炎と 混在する領域（燃焼特性図中(2)

(3) 非常に明るい輝炎が火炎の大半を占める領域 （燃焼特性図中(3)
図中には前述した火炎状態が，燃料流量と燃焼用空 気流量から求めた空気過剩率 $\lambda$ と空気配分比から算出 した一次領域空気過剩率 $\lambda_{p}$ により示されている. な お，燃焼用空気流量が $0.14 \mathrm{~kg} / \mathrm{s}$ より少ない場合につい ては，燃焼用空気が不足し一次領域における燃焼が維 持できなくなることから，実験条件から除外した. 一 次領域の空気過㮃率 $\lambda_{p}$ が 2.0 以上の領域で Blow-off が 発生していることがわかる. 空気流量の増加にともな って安定燃焼領域である(2)の領域は拡大していく.こ れは旋回流により発生する循環領域に効率よく燃焼カ スが取り込まれて噴霧の蒸発と混合が促進されたため と考えられる. 燃焼状態は空気流量よりも空気過㮃率 によって定まることから，一次領域では予混合状態の 火炎が保炎機能を果たしているものと推定される．た だし空気流量 $M_{a}=0.20 \mathrm{~kg} / \mathrm{s}$ を過ぎるころから吹き消え 限界の空気過剩率が低下する傾向を示す.

代表的な火炎形状を表 3 に示す. これは燃焼器下流 側から撮影したものである．空気過剩率の增加により

Table.2 Status of combustion flame

\begin{tabular}{|c|c|c|c|c|}
\hline & \multicolumn{4}{|c|}{ Status of Flame } \\
\hline No. & $\begin{array}{r}\text { Primary } \\
\text { zone }\end{array}$ & Throat & $\begin{array}{r}\text { Secondary } \\
\text { zone }\end{array}$ & Flame \\
\hline (1) & Blow off & Blow off & Blow off & ת \\
\hline (2) & $\begin{array}{l}\text { Blue } \\
\text { Flame }\end{array}$ & $\begin{array}{l}\text { Blue } \\
\text { and } \\
\text { Yellow } \\
\text { Flame }\end{array}$ & $\begin{array}{c}\text { Yellow } \\
\text { Flame }\end{array}$ & \\
\hline (3) & $\begin{array}{l}\text { Blue } \\
\text { Flame }\end{array}$ & $\begin{array}{l}\text { Yellow } \\
\text { Flame }\end{array}$ & $\begin{array}{c}\text { Yollow } \\
\text { Flame }\end{array}$ & \\
\hline
\end{tabular}

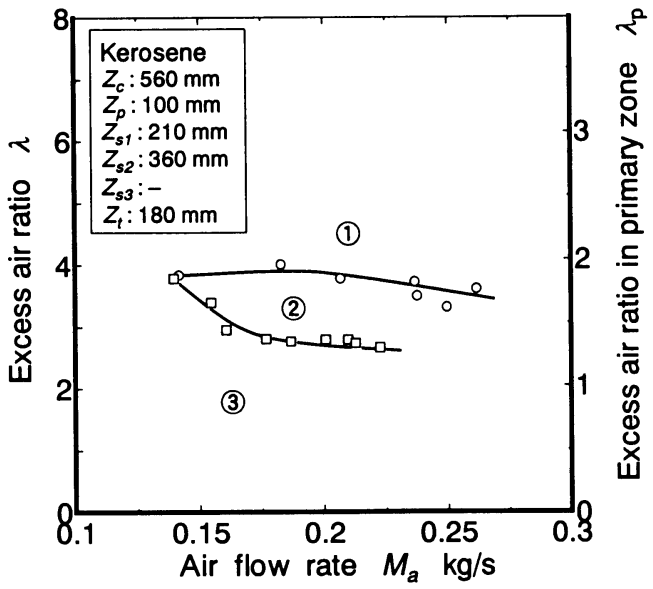

Fig.4 Combustion characteristics on $M_{a}-\lambda$ diagram 
(2)の領域では一次領域およびスロート部における青炎 の占める領域が拡大する. また空気過剩率の増加によ り火炎は短くなるが, 青炎は一次領域全域に広がった ままであり噴霧の局所的な㜣焼により火炎が維持され る状態にはならない，したがってこの燃狫領域では燃 焼ガスの循環が良好に行われ予混合化が促進されてい ると思われる.

一方，(3)の領域では二次燃焼領域に流出した未燃の 燃料が輝炎燃焼する．この場合一次領域の空気過剩率 も低いため, 一次領域でも輝炎燃焼が行われているも のと想定される.

図 4 に示した燃焼特性を燃料流量と空気流量に関す る燃焼特性として示した結果が図 5 である．使用した 燃料ノズルの性能上の流量限界のため, 燃料流量を増 加させた場合の領域(2)の限界, すなわち一次領域が青 炎を主体とする希薄燃焼を行う限界を求めることがで きなかった，しかし，この図から，領域(2)に関する夕

Table.3 Photo-status of flame

\begin{tabular}{|c|c|c|c|}
\hline No. & (2) & (2)-3 & (3) \\
\hline \multicolumn{4}{|l|}{ Flame } \\
\hline Status & Blue & Blue and Yellow & Yellow \\
\hline$M_{0} \mathrm{~kg} / \mathrm{s}$ & 0.20 & 0.19 & 0.17 \\
\hline$M_{r} g / s$ & \multicolumn{3}{|c|}{4.3} \\
\hline$\lambda$ & 3.2 & 2.9 & 2.7 \\
\hline Nozzle & \multicolumn{3}{|c|}{ Delavan 3.00 gallon $/ \mathrm{h} 90^{\circ}-\mathrm{A}$} \\
\hline Fuel & \multicolumn{3}{|c|}{ Kerosene } \\
\hline Combuator & \multicolumn{3}{|c|}{$Z_{\gamma}=100, Z_{F}=180, Z_{\sigma}=260, Z_{\infty}=360, Z_{\sigma}=0, Z_{-}=560 \mathrm{~mm}$} \\
\hline
\end{tabular}

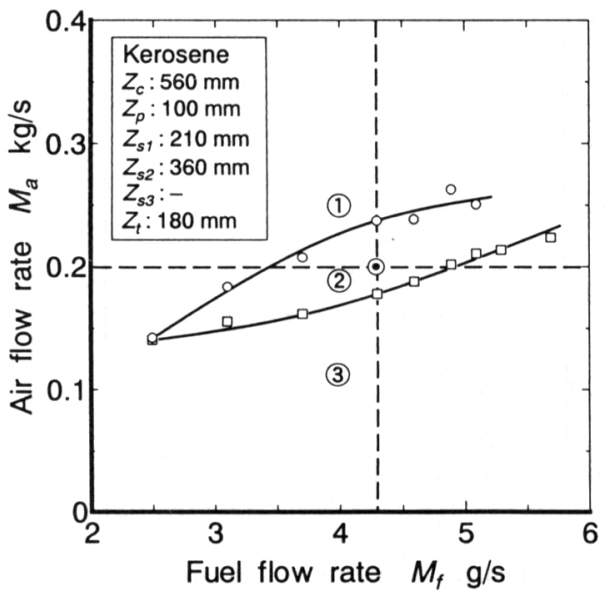

Fig.5 Combustion characteristics on $M_{f}-M_{a}$ diagram
ーンダウン比を燃料流量ベースで 2 倍以上にすること が可能であると判断することができた.

$5 \cdot 2$ 燃焼器出口半径方向の燎赎ガス分析 図 6 に 図 5 中の○印（破線の交点）で示した供給空気量 $M_{a}$ $=0.20 \mathrm{~kg} / \mathrm{s}$, 燃料流量 $M_{f}=4.3 \mathrm{~g} / \mathrm{s}$ における燃焼器出口半 径方向の燃焼ガス温度と燃焼ガス分析結果を示す．燃 焼器出口ガス温度は $1200 \mathrm{~K}$ 以下で半径方向にほぼ一定 の值を示している. CO 濃度は中心で 138ppm と最も 高く, 燃焼器の壁面に近づくにつれて $87 \mathrm{ppm}$ まで低 下している. THC については壁面近くで濃度が増加 するが，その值は $20 \mathrm{ppm}$ 程度である. 両者を勘案す れば二次空気孔の配置不備により壁面近傍での二次燃 焼が不完全であると推定される．ただし THC 濃度が 低くかつ CO 濃度が 200ppm 以下であることから, 燃 焼器全体とすれば完全燃燒に近い燃焼が実現できてい ると思われる． NOx 濃度は $20 \mathrm{ppm}$ 程度まで低減させ ることできた. 半径方向の NOX濃度にほとんど差が 見られないことから, 燃焼器の内部に高濃度の NOx 生成の原因となる局所的な高温部は存在して いないと推定できる．すなわち，NOx 濃度の測定 結果は燃焼領域での燃料と空気の混合状態が燃狫領 域全域にわたり良好で希薄燃焼が達成されているこ
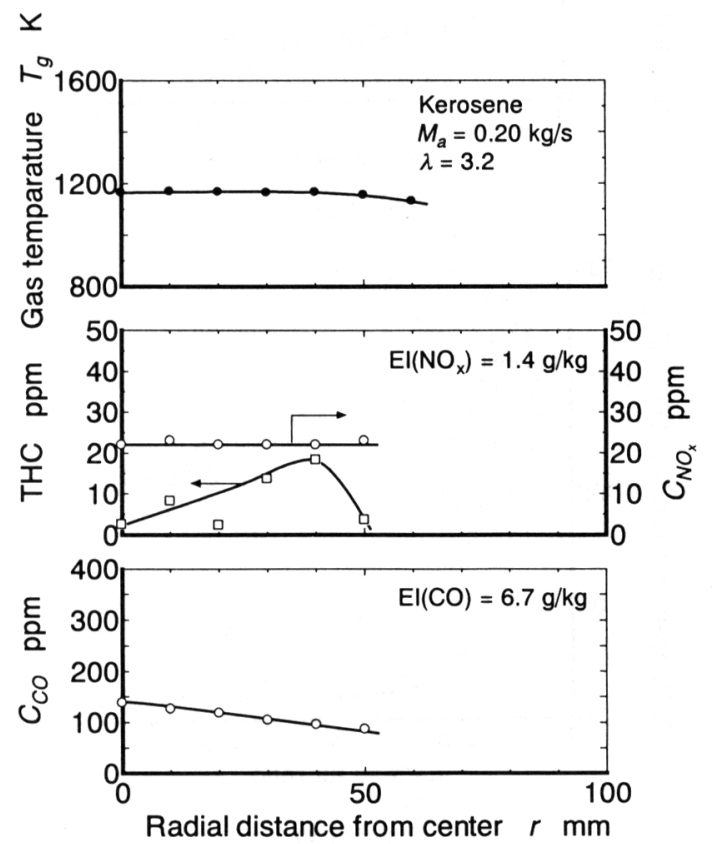

Fig.6 Radial distributions of CO, THC, NOx concentrations and gas temperature 
とを示している. またこのような半径方向の分布をも とに流路面積の重みを掛けた平均化処理を行い，燃焼 筒出口での排出ガス濃度と温度を求めた.

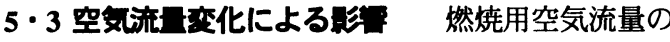
変化に対応した燃焼ガス排出特性を図 7 と 8 に示す.

これは図 5 の図中に示した縦の破線，すなわち燃料流 量を $M_{f}=4.3 \mathrm{~g} / \mathrm{s}$ で一定として空気過剩率をパラメータ として NOx と $\mathrm{O}$ の燃焼カス排出特性を示したもの である. 図 7 の横軸は空気過剩率入である. 実㵋濃度 以外に $\mathrm{O}_{2}$ 排出濃度 $0 \%$ と $16 \%$ に換算したものも示して ある. NOx 排出特性の結果を図 7 （a）に示す．ここ で, 実測濃度を $\mathrm{NOx}, \mathrm{O}_{2}$ 排出濃度を $0 \%$ 己 $16 \%$ に換 算したものをそれぞれ NOx（0\%O2），NOx（16\% $\mathrm{O}_{2}$ ）と表す. NOx は空気過剩率入が高くなるにつれ

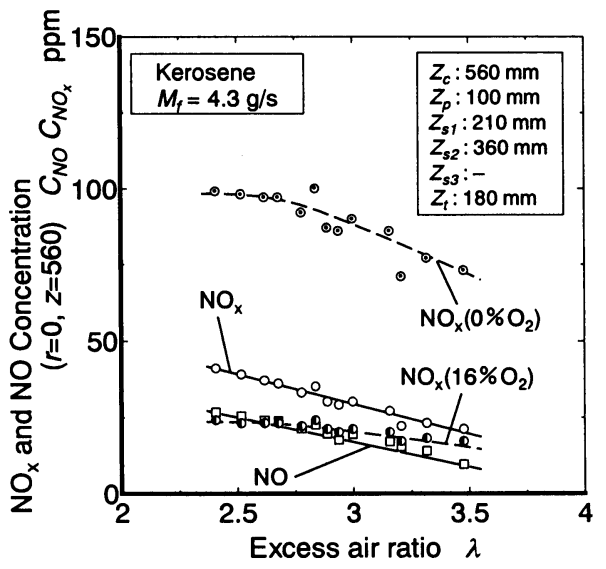

(a) $\mathrm{NO}_{\mathbf{x}}$

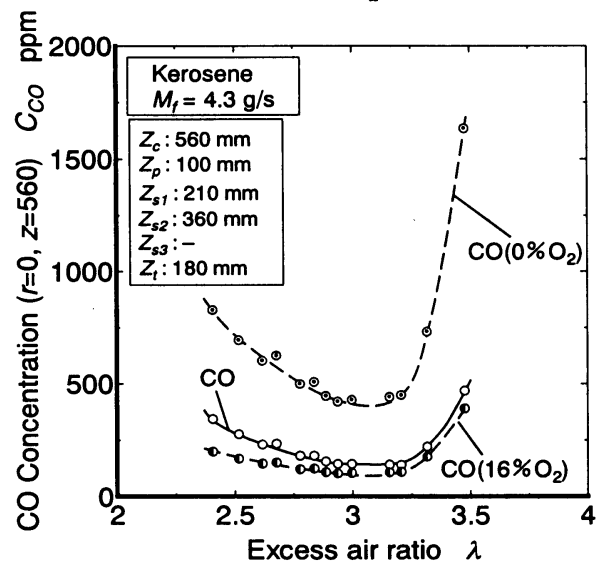

(b) $\mathrm{Co}$

Fig.7 NOx and CO concentrations vs. air flow rate
減少している。一方， $\mathrm{C}$ 濃度は図 7（b）のように, 空気過剩率が $\lambda=3.2$ 以下では NOx 濃度と同様に隇少 するが， $\lambda=3.2$ を超えると NOx 濃度とは逆に空気過 剩率が高くなるほど增加し，空気過剩率入に対して NOx 濃度とはトレードオフの関係になっている.

縦軸を NOx 排出指数 $E I(N O x)$ と CO 排出指数 $E I(C O)$ に換算した結果を図 8 に示す. 燃料流量が一定 であるため空気過剩率とともに空気流量が増加する. $E I(N O x)$ の值は $\lambda=2.6$ 付近で最大值をとり, その後空 気過剩率とともに減少する. 一般的に拡散火炎では空 気過剩率入を大きくしても $E I(N O x)$ は減少しないが, ここでは $E I(N O x)$ の值は予混合火炎のように空気過剩 率とともに減少し, この燃焼器では予混合化が促進さ れていることがわかる. EI(NOX)が最大となる条件で

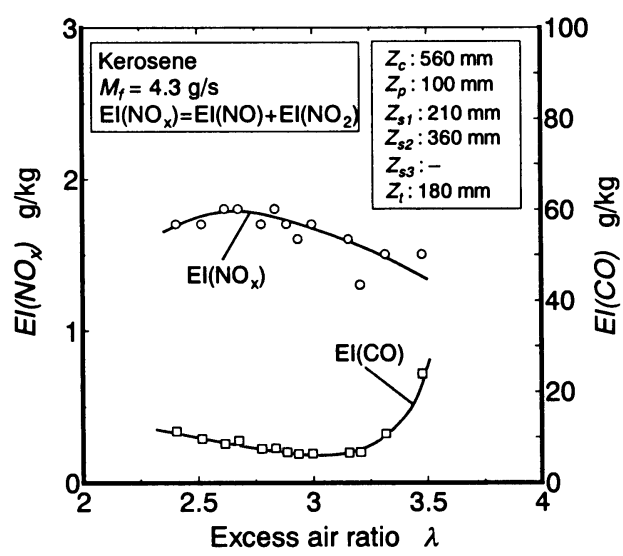

Fig.8 NOx and CO emission indexes vs. air flow rate

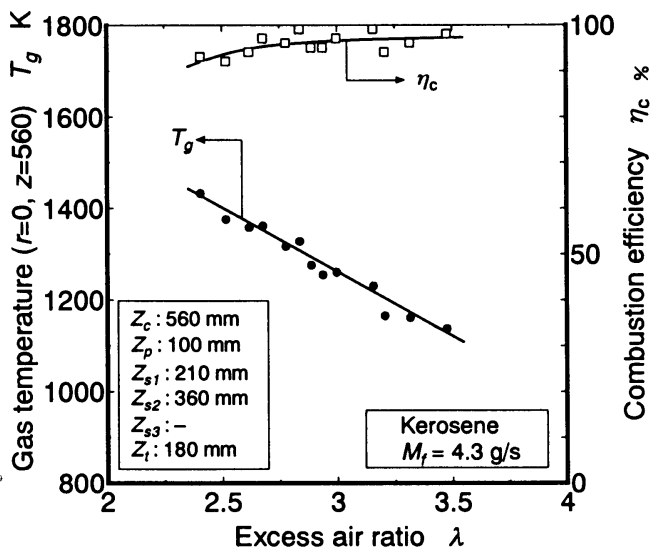

Fig.9 Exhaust gas temperature and combustion efficiency vs. air flow rate 
の一次領域空気過剩率 $\lambda_{p}$ の值はおよそ 13 であり, 燃料と空気が完全に混合されている状態ではないこと を考虑するとこれは一次燃焼の主領域がほほ理論空燃 比での燃焼を行っている状態と考えられる.

$E I(C O)$ の值は $\lambda=3.2$ を超えたあたりから急激に増加す るが，これも予混合化された火炎の部分的な吹き消え 現象によるものと解釈される.

次に,このような NOx 排出挙動を調べることを目 的として, 熱電対を用いて燃焼器出口燃焼ガス温度 $T_{g}$ の測定を行った. 図 9は, 図7や 8 と同様に燃料流 量を $M_{F}=4.3 \mathrm{~g} / \mathrm{s}$ で一定とし空気過剩率をパラメータと した燃泋カス温度とこれを基にした燃焼効率 $\eta_{c}$ の特 性である.

燃焼効率 $\eta_{\mathrm{c}}$ は次式(2)で求めた.

$$
\eta_{c}=\frac{T_{g}-T_{a}}{\Delta T_{t h}}
$$

ここで, $\Delta T_{h}[\mathrm{~K}]$ は燃料が完全燃焼したと仮定した 時に, 次式から算出される理想的な温度上昇分である.

$$
\Delta T_{t h}=\frac{\left(H-L_{h}\right) M_{f}}{M_{a} C_{p a}+M_{f} C_{p f}}
$$

ここでの空気過剩率入の範囲は図 4 の燃焼特性の安 定燃焼範囲である(2)の領域に対応し, 予混合化が促進 され空気量增加による燃焼カス温度 $T_{g}$ の低下が比較 的緩やかに進行している. この温度低下の傾向は, 図 8 に示した $E I(N O x)$ 値の增加と減少の傾向とは一致し ない. この理由としては, 先に述べた通り NOx の生 成には, 一次燃焼領域の燃焼特性が直接関与している ことが挙げられる.

燃焼効率 $\eta_{c}$ は 95\%台であり， 00 の增加する $\lambda=3.2$ を超えても㜣焼効率の低下は起きていない， $\lambda=3.2$ に 対応する一次領域空気過剩率 $\lambda_{p}$ の值はおよそ 1.6 で あり，予混合状態であれば，局所的な吹き消えにより 燃焼が不安定になる条件に対応していることが明らか になった. 一次燃焼領域が不安定になり 0 の濃度が 増加しても燃焼効率の低下を招かないことは, 二次領 域での燃焼が機能していることを示している. また二 次燃焼領域での空気孔の大きさや配置を最適化してい ないので, これを改善すれば, 排ガス問題としての C の排出濃度增加を抑制することは十分可能である と思われる. ここで, 空気過剩率が 25 付近で燃焼効 率が若干低下しているが, これは火炎温度の上昇に伴 い熱損失が增加したことに起因すると考えられ，実際 の燃焼効率は $\varnothing$ 排出指数から見ても低下していない と考えられる.

$5 \cdot 4$ 聮料流目交化による眼空気過剩率をパラ メータとして空気流量を $M_{a}=0.20 \mathrm{~kg} / \mathrm{s}$ で一定とした場
合（図 5 の横破線に対応）の排出カスス特性，燃焼ガス 温度および燃狫効率を図 10-12 に示す. 図 10 に示し た NOx と CO の排出濃度でみると, 空気流量が一定 の場合でも, 燃料流量を低下させて空気過剩率を高め ていくと NOx は減少するが, $C O$ は $\lambda=3.2$ 付近から増 加する. この傾向は図 7 の場合と同じであり，この燃 焼器での NOx と 0 の排出特性が流速や燃焼器負荷 よりも空気過剩率に支配されていることを示している.

縦軸を NOx 排出指数 $E I(N O x)$ と CO排出指数 $\operatorname{EI}(C O)$ に換算した結果を図 11 に示す. 空気過剩率の増加

（燃料流量の減少）よって EI(NOx)は減少するが, $E I(C O)$ は大幅に増加する. 図 12 は出口における燃焼 ガス温度とこれをもとに算出した燃焼効率である. 燃

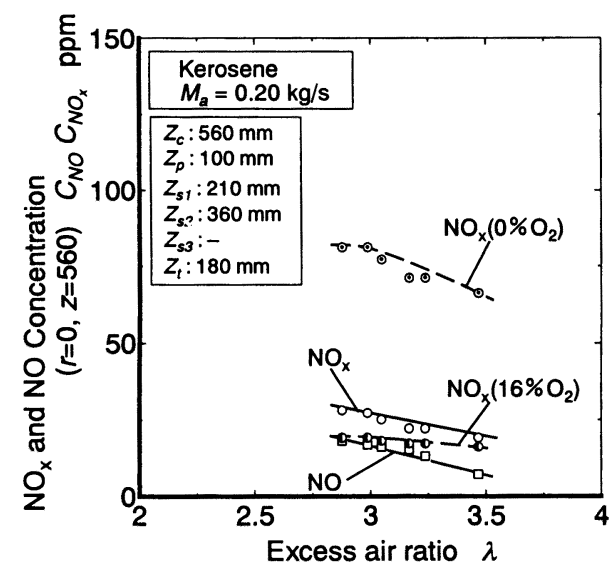

(a) $\mathrm{NO}_{\mathbf{x}}$

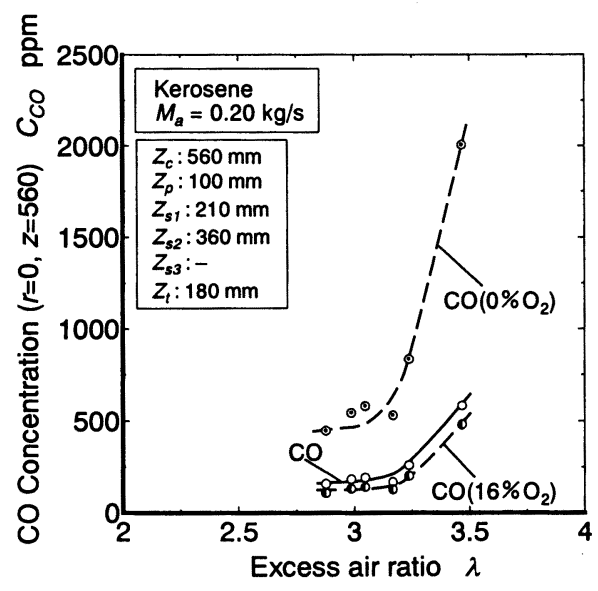

(b) $\mathrm{CO}$

Fig.10 NOx and CO concentrations vs. fuel flow rate 


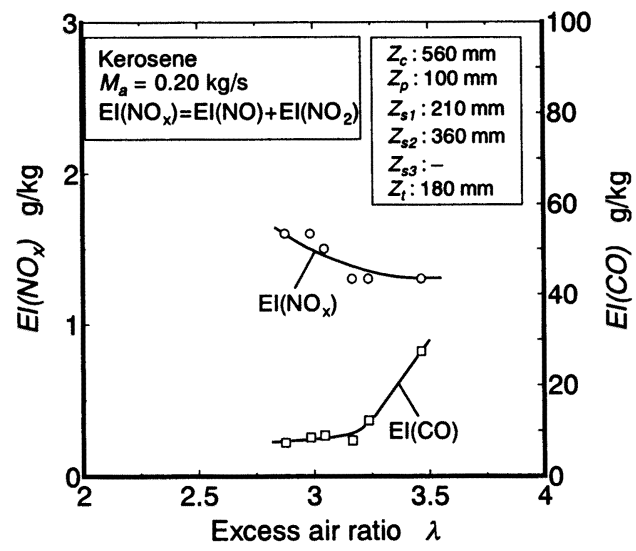

Fig.11 NOx and $\mathrm{CO}$ emission indexes vs. fuel flow rate

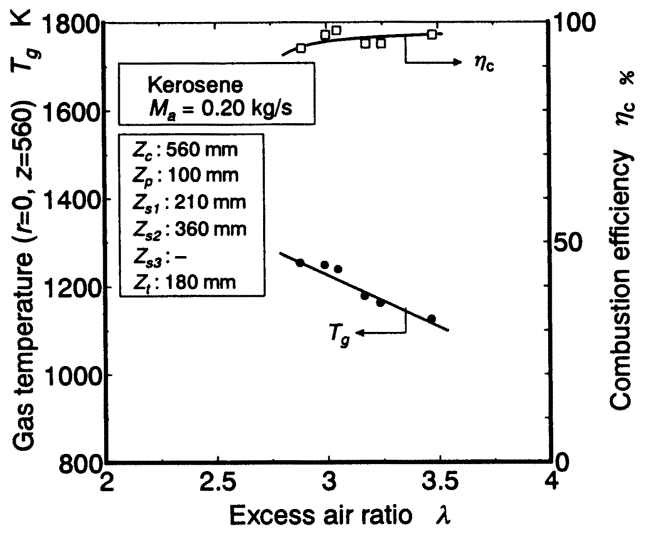

Fig.12 Exhaust gas temperature and combustion efficiency vs. fuel flow rate

焼カス温度 $T_{g}$ は空気過剩率入の増加に伴って低下し ていくが, 燃焼効率 $\eta_{\mathrm{c}}$ では 95\%台を達成できている.

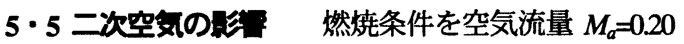
$\mathrm{kg} / \mathrm{s}$ および燃料流量 $M_{f}=4.3 \mathrm{~g} / \mathrm{s}$ で固定し, 燃焼器の二 次空気流入位置を変えた場合の燃焼カス温度と NOx, CO, THC 濃度を図 13 に示す. 二次空気の一段目は $Z_{s l}=210-285 \mathrm{~mm}$ の間で位置を変え, 二段目は $Z_{\mathrm{s} 2}=360 \mathrm{~mm}$ の位置に固定した. この図については, 計 測值はすべて中心軸上の值である. 二次空気の一段目 $Z_{s l}$ の位置を変えても NOx 濃度と燃焼ガス温度に大き な違いは見られない．これは，NOx は一次領域の燃 焼状態に依存していること, また燃焼ガス温度は燃焼

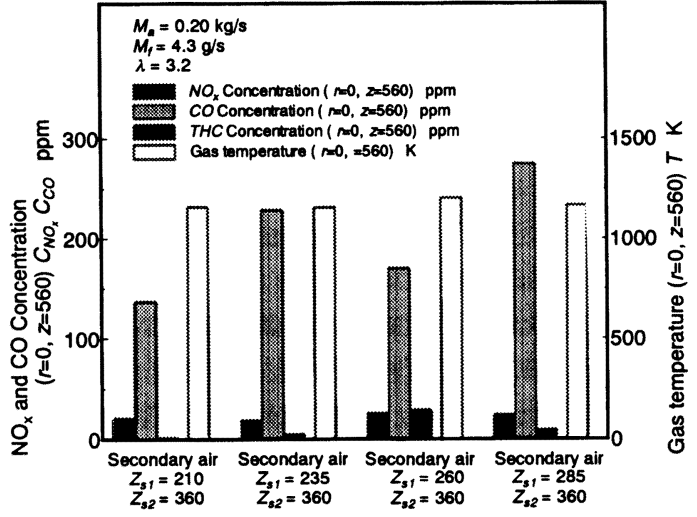

Fig.13 Effect of secondary air position on emissions characteristics

器出口ではすでに燃焼が終了しているため, 途中の燃 焼状態の影響を受けなかったものと思われる.

THCおよび 00 に関しては二次空気の供給位置の影 響を受けることが明らかである. 一段目の二次空気孔 を上流に配置すると基本的に THC と $\mathrm{CO}$ の濃度は減 少するが，THC と $\mathrm{O}$ に対する影響はそれぞれ特異の 傾向を示すこのことは, 両者が二次領域の空気流動 に大きく影響されているためであり, 今後空気孔の大 きさや配置の最適化により, THC と 0 の排出濃度低 減の可能性があることを示唆している.

\section{6. 枯}

上流に遡上する旋回流（Upward Swirl）により燃焼 カススの部を強制的に燃料ノズル近傍に循環させる低 NOx 燃焼器の開発を目的に試験用の予混合燃焼器を 製作した. 燃料として灯油を使用し，火炎形状，燃焼 カス特性, 燃焼器出口温度分布を調べたところ, 以下 の結果が得られた.

（1）燃烧器の一次燃焼領域で不輝炎燃焼が観察され, 遡上する旋回流による燃焼カススの循環効果による液体 燃料の予混合化された燃焼を実現することができた. また混合促進の効果により燃焼器出口で均一化された 燃焼ガス分布を得ることができた.

（2）燃焼器全体としての空気過剩率が 3.2 以下の希 薄条件で CO 濃度が低い值をとることが明らかになり 燃焼効率の高い希薄燃焼を実現する燃焼器を開発する ことができた.

（3）燃焼器一次領域の空気過剩率を 2.0 以下の希薄 側で安定して作動させることが可能になり, 燃焼器出 
口 $\mathrm{NOx}$ 濃度を $18 \mathrm{ppm}\left(16 \% \mathrm{O}_{2}\right.$ 換算) 程度の低濃度と することができた.

\section{当支献}

(1) 巽, 日本ガスタービン学会誌, $31-4$ （2003）, 279-281.

(2) 伊藤, 日本ガスタービン学会誌, 31-5（2003）, $289-300$.

(3) 小林，クリーンエネルギーVol.10 （2003），43 $-46$.

(4) 君島, 笠木, 機論 B, 70-692（2004），1020－ 1027.

(5) 井上, エンジンテクノロジー, 18 (2002)， 34-37.

(6) J.M.Beer, J.Inst. Energy, 68（1995）, 2 - 10.

(7) M.Correa, 27th Int. Symp. on Comb. (1998), 1793 - 1807.

(8) 中島, 竹村, 他 2 名, 日本ガスタービン学会誌, 31-5 (2003)，305-310.

(9) 市原, 大久保, 他 3名, 第 15 回ガスタービン秋 季講演会（秋田），（2001），207-211.

(10) 藤, 日本ガスタービン学会誌, 32-1（2004）, $21-26$.

(11) 渡辺，省エネルギー，53-9（2001），33-39.

(12) 山田, 林, 他 1 名, 第 30 回ガスタービン定期講 演会（富山），(2002），41－46.

(13) 市川, 熊倉, 他 1 名, 機論 B, 69-977（2003）, 155-161.
(14) 市川, 熊倉, 他 1 名, 機論 B, 70-692（2004）, 1036 - 1042.

(15) Arai, IJPGC-2000, CD-15073, (2000), 1-10.

(16) T.Shinkawa and M.Arai, IJPGC-2001/FACT, CD 19105 (2001) , 1-7.

(17) 新井, 新川, 他 1 名, 化学工学論文集, $28-6$ (2002)，686-692.

(18) 特許申請中, 特願 200432933, 特願 200432941, 特願 2004-32943, 特願 2004-32945.

(19) M.Katsuki and T.Hasegawa, 27th Int. symp. on Comb. (1998), 3135-3146.

(20) O.Akinyemi, M.A.Toqan, 他 4 名, J Inst. Energy, 75 (2002), 52-58.

(21) M.Arai and H.Hiroyasu, 他 2 名, JSME Int. J. Ser.B, 34 4(1991), 540-547.

(22) C.M.Cha, J.C.Kramlich, 他 1 名, $27^{\text {th }}$ Int. Symp. on Comb. (1998), 1427-1434.

(23) M.M.Vahdati and P.O'Nions, J.Inst. Energy, 73(2000), 1217.

(24) S.Hayashi and H.Yamada, Int.Combust. Symp. (2000), 2443-449.

(25) M.Arai, K.Amagai ,T.Mogi Trans. ASME J. Energy Resources Tech., 123(2001), 44-49. 